УДК 141:165.742](410)»18»

ORCID ID: 0000-0001-9266-5672

Тернова Марина Володимирівна, кандидат філософських наук, старший викладач кафедри суспільних наук. Київський національний університет театру, кіно i телебачення імені I. К. Карпенка-Карого, Київ

Терновая Марина Владимировна, кандидат философских наук, старший преподаватель кафедры общественных наук. Киевский национальный университет театра, кино и телевидения имени И. К. Карпенко-Карого, Киев

Maryna Ternova,

Ph.D of Philosophical Sciences, Senior Lecturer of Social Sciences Department. Kyiv National

I. K. Karpenko-Karyi Theatre, Cinema and Television University, Kyiv

\title{
ІСТОРИКО-ФІЛОСОФСЬКЕ ПІДІРУНТЯ АНГЛІЙСЬКОЇ ГУМАНІСТИКИ ДРУГОЇ ПОЛОВИНИ ХІХ СТОЛІТТЯ
}

Анотація. У статті сфокусовано увагу на історико-філософських надбаннях, які забезпечили теоретичне підгрунтя гуманістики другої половини XIX століття. Оскільки на англійських теренах гуманітарне знання формувалося на чітко виражених принципах спадкоємності, врахування досвіду, що передував другій половині XIX століття вкрай важливе. Формування такого досвіду передбачало також відкритість як до нових напрямків досліджень, так і до передбачення шляхів розвитку соціальної, етичної та практичної філософії.

Однією зі специфічних ознак даної статті є використання засад культурологічного аналізу, серед яких особливого значення надається персоналізації досліджуваного матеріалу. Персоналізація - структурний елемент біографічного методу, він дає змогу підтвердити людинотворчий характер культури, що його послідовно опрацьовують українські науковці.

У статті також наголошено значення поступового формування регіонального підходу, який, починаючи від XVIII століття, визначався елементами діалогу англо-німецької та англо-французької гуманістики.

Ключові слова: історія філософії, естетика, мистецтвознавство, емпіризм, скептицизм, досвід, «прекрасне - піднесене», «герой — героїзм», «загальне почуття».

Постановка проблеми та актуальність дослідження. Сучасна гуманістика, незалежно від того, де і в яких умовах вона розвивається, співвідносить свою теоретичну спрямованість 3 тими традиціями, які впродовж значного історичного періоду накопичувала конкретна країна. Відтак із територіально-регіональних елементів поступово формується, наприклад, європейський культурний простір як цілісне явище, що при цьому завжди має певну кількість самобутніх і самоцінних елементів.
Одним 3 них є англійська гуманістика, а розгляд історико-філософського підгрунтя певного етапу її розвитку спирається на теоретико-методологічні засади аналітичного, порівняльного та культурологічного підходів. Стосовно останнього, його потенціал буде виявлений завдяки персоналізації -структурного елемента біографічного методу, ставлення до якого на англійських теренах було неоднозначним. Так, Р.Дж. Коллінгвуд - відомий філософ, історик науки, автор фундаментального дослідження «Принципи мистецтва», хоча і за- 
лишив свою «Автобіографію», проте заперечував жанр «біографізму», вважаючи його антиісторичним, оскільки життя людини, на його думку, слід визначати суто біологічними процесами народження і смерті (Коллингвуд, 1980: 290-291).

Тему статті актуалізує і факт появи у другій половині XIX - першій половини XX століття, низки публікацій, предметом яких був розгляд життєво-творчого шляху таких непересічних постатей в історії англійської гуманістики, як Ф. Бекон та Д. Юм. Оскільки розгорнутий аналіз означених фактів представлений у грунтовній монографії В. Менжуліна «Біографічний підхід в історико-філософському пізнанні» (2010), ми лише зафіксуємо, що визнаний німецький історик філософії Куно Фішер (1824-1907), скрупульозно реконструюючи біографію Ф. Бекона, наголосив на низці фактів, які засвідчили як його політичну безпринципність, так і схильність до морально-етичної вседозволеності (Фишер, 2003).

Щодо інтерпретації біографії Д. Юма, вона взагалі спровокувала скандал в європейському науковому середовищі після оприлюднення статті Ернеста Мосснера, на сторінках якої обговорювалося наступне запитання: «Хто такий Д. Юм відданий шукач істини чи шарлатан від філософiï»? (Mossner, 1950).

Аналіз досліджень $\boldsymbol{i}$ публікацій. Означена у статті проблема була об'єктом теоретичного аналізу в працях Н. Жукової, Л. Левчук, О. Маламури, В. Менжуліна, Н. Наконечної, О. Оніщенко, В. Панченко, що дає підстави оцінити дослідницький простір, в якому розглядалася англійська гуманістика, як багатоаспектний. Це й історико-філософські модифікації біографізму, й історія естетики, і «естетизм» О. Уайльда, і англійська модель неопозитивізму, і проблема понятійно-категоріального забезпечення гуманітарного знання, і елітаризм сучасної англійської художньої літератури. Публікації означених авторів дають підстави говорити про неабиякий інтерес сучасних науковців до цієї моделі європейського культуротворення.

На нашу думку, зацікавленість специфікою розвитку саме англійської гуманістики має свої причини, серед яких, передусім, наголосимо на iii традиціоналізмі та послідовній дії принципу спадкоємності. Дослідницькому простору Англії не властиві ані карколомні зрушення чи стрибки, ані «зони мовчання», коли б у теоретичних напрацюваннях наставала пауза. Якщо ж припустити можливість такої «паузи», вона швидко і майже непомітно для стороннього погляду, заповнюва- лася б розмірковуваннями тих, хто рухався, так би мовити, у валці видатного мислителя.

Означене нами, пояснює той обсяг матеріалу, що його ми плануємо охопити у цій статті - від 50-70-х років XVIII до другої половини XIX століття, оскільки «зміст» історико-філософського підгрунтя, яке $\epsilon$ предметом наших наукових інтересів, своїми витоками сягає часів Френсіса Бекона (1561-1626), Джона Локка (1632-1704), Антоні-Ешлі Шефтсбері (1671-1713), Джорджа Берклі (1685-1753), Девіда Юма (1711-1776), Едмунда Бйорка (1729-1787). Наразі зазначимо, що видатний італійський філософ Антоніо Банфі (18861957), аналізуючи стан європейської гуманістики на межі XVII-XVIII століть, особливу увагу концентрує на досвіді англійців, виокремлюючи, зокрема, постать Джозефа Аддісона (1672-1719) драматурга, поета і публіциста, який стояв біля витоків англійського Просвітництва, «з його блискучими статтями в журналі “Глядач” (1712)», який вважався потужним популяризатором тогочасного мистецтва (Банфи, 1989: 176). Принагідно наголосимо, що значний розголос мали і п’єси Дж. Аддісона, зокрема драма «Катон» (1713), яка впродовж кількох театральних сезонів не сходила зі сцени провідних англійських театрів. Оскільки сучасники цінували Аддісона як автора драматичних творів, комедію «Барабанщик» (1714) він оприлюднив під псевдонімом, хоча і вона мала успіх у частини глядачів.

Поза сумнівом, на увагу заслуговують і традиції гуманістики першої половини XIX століття, які сформувалися завдяки досить виразним естетичним шуканням, передусім, Томаса Карлейля (1795-1881). Ми цілком свідомо заявляємо такий об'ємний матеріал, хоча за нормативами статті приречені на певну строкатість викладу. Проте, тільки рухаючись таким шляхом, можна підтвердити нашу оцінку самобутності англійської гуманістики.

Mema cmammi. У контексті означеного, мета статті полягає, по-перше, у персоналізації англійської гуманістики, починаючи від межі XVII-XVIII століття, й акцентуванні значення конкретних історико-філософських напрацювань; по-друге - у систематизації найбільших досягнень гуманітарного знання, які зумовили його беззастережний естетико-мистецтвознавчий злет в умовах другої половини XIX століття; i, по-третє - актуалізації феномена регіонального підходу у контексті досліджуваної проблеми.

Виклад основного матеріалу. На нашу думку, розгляд історико-філософського підгрунтя анг- 
лійської гуманістики другої половини XIX століття вимагає послідовного опертя на періодизацію іiї історико-культурного руху. Серед наявних моделей увагу, зокрема, привертає періодизація XVIII - початку XX століття, запропонована Оленою Оніщенко. Хоча ця модель «будується» на аналізі розвитку естетики та естетичної свідомості як своєрідної серцевини цієї науки, вона, по суті, відбиває ситуацію з гуманітарним знанням в цілому.

Окреслюючи три головні етапи, О. Оніщенко зазначає:

Перший розпочинається з середини XVIII ст. і пов'язаний з іменами А. Шефстбері, Д. Юма та Е. Бйорка; наступний етап - 3 першої половини XIX ст. й ототожнюється з феноменом руху прерафаелітів; третій етап охоплює період 3 другої половини XIX і до початку XX ст. Він асоціюється з іменами А. Гранта та О. Уайльда (Оніщенко, 2010: 306).

Оскільки у цій статті нас цікавить англійська гуманістика взагалі, а не лише ії̈ естетична складова, вважаємо за доцільне наголосити на тих властивих для неї процесах та фактах, що передують становленню морально-естетичної позиції А.-Е. Шефтсбері, значення якої у теоретичному збагаченні європейського дослідницького простору визнається до сьогодні. Загальновідомо, що основні теоретичні праці Шефтсбері «Моралісти» (1709) (діалог про об'єктивність неоплатонівського представлення трьох видів природи, якими «керує» «дух» або «світова душа») та «Характеристики людей, вдач, думок, епох» (1-3 тт., 1711) $€$ надбанням початку XVIII століття, коли на теренах англійської філософії була відчутна боротьба раціоналізму та емпіризму.

Позицію емпіризму, як відомо, активно підтримував і аргументував Дж. Локк. Виступаючи проти тези щодо існування у нашому розумі «вроджених ідей», «представники емпіризму доводили, що жодних вроджених ідей або принципів у свідомості людей нема і бути не може» (Петров, 2001: 7). За мірками тогочасної філософії позиція Локка мала новаторський характер, оскільки прийняття тези про «вроджені ідеї» принижувало значення досвіду — найважливішого чинника, завдяки якому людиною отримується достовірне знання.

Принциповість позиції Локка для англійської гуманістики означеного періоду була вкрай важливою, оскільки особливу вагу має, як зазначає К. Шадманов у статті «До історії становлення системи основних понять англійської філософії: філософська площина» (2018). «...аналіз механізму “входу” ідей і концепцій у мережу категоріальних структур філософського концептуального апарату, тобто виявлення ролі й значення філософсько-світоглядного знання в становленні системи категорій англійської філософії в контексті формування принципів наукового пізнання і генези власне наукового знання» (Шадманов, 2018: 26).

К. Шадманов наголошує на значенні діалогічної форми викладу наукового матеріалу, якою користувався не лише вже згаданий нами А.Е. Шефтсбері, а й інші науковці. Це вкрай важливе зауваження, адже серед них, що наголошує К. Шадманов, були «природознавці, вчені-експериментатори, письменники, поети, державні діячі». Конкретизуючи означений перелік, так би мовити, професійної приналежності, виокремимо імена Томаса Мора (1478-1535) - юриста, філософа, письменника-гуманіста; Філіпа Сідні (1554-1586) - поета; Френсіса Бекона (15611626) - філософа, історика, політика; Джона Донні (1572-1631) - проповідника, поета-метафізика, твори якого «Анатомія світу» (1611) та «Розвиток душі» (1612) вважаються чи не найкращими зразками англійського літературного бароко. Це показовим чином засвідчує інтерес тогочасної інтелектуальної еліти Англії не лише до філософського знання, а й до спроб практичного втілення його надбань у життя суспільства, що, наприклад, підтверджує діяльність на посту Лорда-канцлера Томаса Мора - автора славетної «Утопії» (1516) .

Реконструюючи «філософську площину» XVI - початку XVIII століття і намагаючись не обмежити себе хронологічно-фактологічним відтворенням процесу «прирощування» понять у тогочасній філософії, К. Шадманов оперує, у контексті означеної проблеми, поняттям «безпередпосилочне» (рос. «беспредпосылочное»), автором якого $\epsilon$, вочевидь, він сам. За всієї фонетичної незграбності, воно несе в собі важливий зміст, адже «...безпередпосилочне знання неможливе. Натомість передумови теоретичного знання - це завжди поставлені й такі, що постійно формуються загальнокультурним контекстом, вихідні уявлення про предмет дослідження» (Шадманов, 2018: 27).

Наразі зазначимо, що матеріал, який вже представлений нами, доцільно розглядати як «безпередпосилочний» до аналізу позиції Девіда Юма (1711-1776) - найважливішої постаті у логіці розвитку філософських, історичних та економічних знань, спадщина якого помітно вплинула 
як на англійську гуманістику усього ХІХ століття, так і на теоретичні позиції низки європейських мислителів. Констатуючи полемічне ставлення до історико-філософської орієнтації Д. Юма з боку німецької філософської спільноти, Ю. Перов наголошує прийняття його ідей І. Кантом, позиція якого опонувала негативній оцінці інших. «Одним 3 небагатьох винятків на тлі типового для німецьких філософів (після Канта) негативного ставлення до Юма став А. Шопенгауер, який завважував, що на одній сторінці Юма можна навчитися більшому, ніж в усіх творах Шлейєрмахера, Гегеля і Гербарта, разом узятих» (Петров, 2001: 5).

Позитивна, навіть емоційно піднесена, оцінка напрацювань Юма з боку Шопенгауера, на нашу думку, стосується і його попередників, оскільки юмівський емпіризм лише ланка у складному русі цього комплексу ідей від Дж. Локка, Ф. Бекона та Дж. Берклі, адже Д. Юм «демонстрував свою прихильність філософському емпіризму і солідарність 3 основними висновками попередників критикою вроджених ідей і визнанням досвіду єдиним джерелом наших знань» (Петров, 2001: 9).

Спираючись на потенціал персоналізації, спробуємо окреслити як постать самого Юма, так і ті його ідеї, котрі вважалися актуальними й у другій половині XIX століття, тобто майже через сто років після його смерті. Як відомо, Юм залишив «Автобіографію», написану за п'ять місяців до смерті, яку пізніше оприлюднив його друг відомий економіст Адам Сміт.

«Автобіографія» підтверджує схильність Д. Юма до іронічно-скептичного ставлення і до власної персони, і до своїх сучасників, їхнього стилю життя й рівня розуміння, запропонованих ним моделей світобачення. Видатний англійський філософ, шотландець за походженням, з вражаючою відвертістю реконструює свій життєво-творчий шлях, позначений у перші десятиліття бідністю, матеріальною залежністю від родичів, невдачами у спробах продати свої перші «Трактати».

3 усією відповідальністю можна стверджувати, що Д. Юм належав до тієї спільноти людей, які «зробили себе самі». Поступово його становище починає виправлятися: він досить вдало показав себе, працюючи секретарем впливових вельмож, від 1747-го два роки служив в армії ад'ютантом генерала. Як зазначає сам Д. Юм,

за все моє життя ці два роки були майже єдиною перервою у моїх заняттях; я провів їх приємно і в доброму товаристві, а моє матеріальне становище завдяки значному забезпеченню і ощадливості зросло настільки, що я вважав себе вже досить забезпеченим, хоча мої друзі посміхалися, коли я говорив це; отже, я мав тоді близько тисячі фунтів (Юм, 2001а: 27).

1749-1752 роки стають переломними в кар'єрі Юма-філософа: його роботи, зокрема «Політичні бесіди» та «Дослідження принципів моралі», не лише друкують, а й активно обговорюють у професійному середовищі. Прийнявши пропозицію стати бібліотекарем «Товариства юристів» (1752), Юм починає працювати над масштабним дослідженням «Історія Англії», сфокусувавши увагу на домі Стюартів.

На сторінках «Автобіографії» Д. Юм зізнається, що чекав на підтримку й захоплене ставлення своїх сучасників, коли вони побачать, що він пише об'єктивну історію, не оглядаючись ані на владу, ані на вигоду, ані на авторитет чи «голос народних забобонів». Очікуючи овацій, Юм пережив «жахливе розчарування»:

Я був зустрінутий криком обурення, ганьби, ненависті англійців, шотландців та ірландців, віги й торі, церковники і сектанти, вільнодумці й святенники (religionist), патріоти і придворні - всі об'єдналися у пориві люті проти людини котра насмілилася з повагою оплакати долю Карла I та графа Страффорда... (Юм, 2001а: 29-30)

Ми цілком свідомо так детально цитуємо Д. Юма, адже його нотатки, з одного боку, ілюструють граничну «шаруватість» англійського суспільства, а 3 іншого здатність цих «шарів» об'єднуватися, коли хтось зазіхає на сталі традиції. Незважаючи на досить складну морально-психологічну ситуацію, в якій опинився Юм, він продовжував активно працювати, написавши «Історію Тюдорів» та прийнявши пропозицію працювати в англійській дипломатичній місії у Парижі (1766).

Так, Д. Юм встановлює особистісні стосунки 3 Ж.-Ж. Руссо, Ш. Монтескьє, Ж.-Л. д’Аламбером, К.-А. Гельвецієм, листується з Вольтером. Французькі просвітники активно підтримують Д. Юма, особливо у тому аспекті, де він артикулює антиклерикальну позицію. Пізніше він робив спроби популяризувати наукові розвідки французьких мислителів на англійських теренах, хоча окремі ідеї Руссо сам оцінював як екстравагантні (Юм, http://solecity.ru/philosophy/david-um).

Завершивши роботу в Парижі й повернувшись на батьківщину, Д. Юм створює «Едінбургське філософське товариство», до складу якого увійшли А. Сміт, А. Монро, Х. Блейєр, А. Фергюссон, які продовжували працювати і після смерті Юма у 1776 році, намагаючись утверджувати 
шотландську філософію як самостійне явище, що не має розчинитися у просторі англійської гуманістики. Сьогодні теоретична спадщина Юма це ціла низка історико-філософських досліджень, 3-поміж яких виокремимо «Трактат про людську природу» (1739-1740), «Дослідження про людське пізнання» (1748-1758), «Природна історія релігії» (1757).

Предметом самостійного аналізу може бути й есеїстика Юма, яка, на превеликий жаль, повністю не дійшла до XX століття, але те, що нам відомо, вражає багатоаспектністю інтересів філософа: «Про самогубство», «Епікуреєць», «Платоник», «Скептик», «Стоїк». Останні два есе, на нашу думку, слід співвідносити із самим Д. Юмом. Ми вже акцентували іронічно-скептичний відтінок, що властивий його «Автобіографії», проте це відзначають практично усі дослідники теоретичної спадщини філософа, світоставлення Юма слід кваліфікувати як радикальний скептицизм. Отож Ю. Перов звертає увагу на те, що у давньогрецькому теоретичному просторі поняття «скептик» мало дещо інше тлумачення, ніж його сьогоднішнє розуміння. Загальновідомо, що для давніх греків та римлян скептик (skeptikos) людина, яка розглядає чи досліджує, є антиподом догматикові та академісту, оскільки «скептик», на відміну від інших, перебуває у процесі пошуку істини (Петров, 2001: 10-11). На нашу думку, подібна характеристика повністю відповідає сутності Юма-вченого, який усе життя шукав, знаходив і відстоював істину.

Дотичним до життя Д. Юма $є$ i поняття «стоїк», що підтверджують останні роки його життя. В «Автобіографії» він чітко фіксує 1775-й як рік, коли у нього виявили важке захворювання, що може мати смертельні наслідки. 3 цього приводу Юм залишає такий запис: «...я думаю, що людина 65 років, помираючи, не втрачає нічого, окрім кількох років нездужання» (Юм, 2001a: 33). Тож, характеризуючи Юма як скептика, доцільно, на наше глибоке переконання, віддати йому належне і як стоїку.

Слід визнати, що серед своїх сучасників, котрі формували простір англійської гуманістики XVIII століття, Д. Юм був найбільш професійно переконливим i, так би мовити, відкритим як до нових напрямків досліджень на теренах гуманітарного знання, так і до передбачення шляхів розвитку соціальної, моральної та практичної філософії.

На нашу думку, враховуючи формат статті, доцільно особливу увагу сконцентрувати на «Трактатах» Д. Юма, матеріал яких дає змогу ви- значити його позицію як «людиноцентристську». Філософ намагається досліджувати численні проблеми, орієнтуючись на потенціал конкретної людини, оскільки підняті ним питання співвідносні з іiі життям. Так, у процесі розгляду «різних видів філософії» та процесу «походження ідей» дещо несподівано в трактаті «Дослідження людського пізнання» окреслюється, так би мовити, оціночний розділ щодо «скептичних сумнівів стосовно діяльності розуму»,

Означений розділ «побудований» на глибокому переконанні Д. Юма, з одного боку, щодо здатності переважної більшості людей скептично ставитися до можливості всебічного пізнання «об'єкта їх уваги», а 3 другого - сам філософ демонструє певний скепсис щодо можливостей розуму. 3 цього приводу Юм, зокрема, зазначав: людина досить вправно діє, коли йдеться про відомі їй події, наприклад, схід та захід сонця. Однак чи буде вона так само впевненою, якщо матиме справу 3 невідомим їй предметом, явищем або процесом?

Стимулюючи читача до роздумів і самостійності правильної відповіді, філософ наводить такий приклад:

Дайте два гладких шматка мармуру людині, яка не має жодного уявлення про природничу філософію, і вона ніколи не відкриє, що ці шматки пристануть один до одного так, що буде коштувати значних зусиль аби роз'єднати їх за прямою лінією, тоді як під тиском збоку вони викажуть досить малий супротив. (Юм, 2001b: 64).

Якщо відштовхуватися від цього прикладу, потрібно «побудувати» такий ланцюг: розум знання - досвід, 3 якого слід одразу вилучити «знання», оскільки людина нічого не знає про шматки мармуру. Наразі, слід знехтувати і «розумом», адже він не допомагає людині в скрутному становищі. Таким чином, позитивної оцінки заслуговує «досвід» - єдина стабільна й надійна «константа пізнання».

Надзвичайно висока оцінка «досвіду», до потенціалу якого Юм звертається у різних своїх працях, повністю не затуляє, проте, значення «розуму», примушуючи філософа шукати інші аспекти людського життя. Це дає можливість розумовій діяльності розкрити власні можливості. При цьому Юм висловлює застереження стосовно доцільності опертя лише на власний розум, глузд чи міркування, оскільки вони, «діючи самостійно і відповідно своїм найбільш загальним принципам, безумовно підривають себе самих і не залишають ані найменшої очевидності жодному з суджень як у філософії, так і в буденному житті» (Юм, 2001b: 178). 
Означену теоретичну позицію Д. Юм намагається трансформувати у світ звичайної людини, яка повинна поважати «загальні принципи», хоча власне їй до вподоби «слідувати» за своїми «духами» та «афектами», «відчувати готовність кинути у полум'я всі свої книги та папери» і ніколи в житті не жертвувати задоволеннями життя заради розмислів та філософії» (Юм, 2001b: 181-182). Слід визнати, що звернення Д. Юма до аналізу почуттєвої природи людини, робить його теоретичні шукання як досить переконливими, так і такими, що підтверджують його позитивне ставлення до зв'язку філософського та психологічного знання.

Зацікавлене ставлення англійського скептика до почуттєвої культури людини підтверджується достатньо розгорнутою естетичною проблематикою, яка становить помітну частину його теоретичної спадщини. Відтворюючи наріжні шляхи підходу й іiі опрацювання, слід враховувати таке: Д. Юм та інші представники емпіризму відстоювали дві, як показав час, помилкові ідеї щодо існування «загального почуття» та «законів краси».

Вихідним положенням юмівського розуміння естетики $є$ наголос на значенні естетичного ставлення, яке стимулюється естетичним почуттям. Серед «відтінків» естетичного почуття найважливішими, на думку Юма, є почуття прекрасного й піднесеного. Слід зауважити, що не лише серед низки чуттєвих модифікацій естетичного почуття, а й порівняно 3 почуттям прекрасного, «піднесеному» впродовж XVIII століття надавалося особливого значення. Коментуючи таку ситуацію, В. Панченко зазначає:

Європейська естетична думка зосередила увагу на категорії піднесеного тільки у XVIII столітті. В цей період трактат Псевдо-Лонгіна знову привернув увагу дослідників і став предметом вивчення й коментування. У Франції Сільвейн виступив із “Трактатом про піднесене" (1732)... (Панченко, 2010b: 99-100).

Концентруючи увагу на англійській гуманістиці, В. Панченко, зокрема, наголошує таке:

...поняття піднесеного почали широко використовувати Юм, Шефтсбері, Хатчесон. У 1747 р. Дж. Бейлі опублікував працю “Досвід про піднесене”. I, нарешті, в 1757 р. з'явився найбільш узагальнений твір з цього питання, трактат англійського філософа Едмунда Бйорка "Філософські дослідження про походження наших ідей піднесеного і прекрасного" (Панченко, 2010b: 100).

Спираючись на сучасне розуміння структури естетичних категорій, Е. Бйорк зайняв позицію, що в умовах сьогодення оцінюється як помилко- ва, і поставив «піднесене» поперед «прекрасного». Проте «піднесене» - це «прекрасне», що перебуває в русі до ідеалу, а відтак у динаміці формування структури естетичних категорій діє така залежність: прекрасне - піднесене - ідеал як ціль, що спонукає до дії. Означене артикулює процесуальний і динамічний характер низки категорій, які впливають на відтворення наріжної сутності естетики як науки.

Водночас, у логіці розгляду питань, піднятих на сторінках цієї статті, для нас не стільки важливо наголосити теоретичні прорахунки філософів XVIII століття, скільки аргументувати тезу про спільність англійських гуманістів в опануванні певних аспектів гуманітарного знання. Нашу позицію підтверджує й аналіз проблеми естетичного смаку, що дав можливість як порівнювати розмисли Юма з науковими розвідками I. Канта, так і констатувати, що, відштовхуючись від юмівської позиції, визнання почуттєвого підгрунтя «смаку», вироблення «норми» смаку, опанувати яку зможуть лише окремі, схильні до відчуття «витонченості» особи, - Кант підняв теоретичний рівень осмислення проблеми значно вище, ауцентувавши суспільно-індивідуальний характер смаку, що дало змогу наголосити на проблемі «вибору». Тож показовою є позиція В. Панченка, яка засвідчує, що важливим естетичним чинником смаку є почуття задоволення, а це відрізняє смак чи то від утилітарного, чи то морального почуття. Такі теоретичні «побудови» I. Канта, по суті, залишали на маргінесах розмисли Д. Юма, який надавав занадто великої ваги моральним почуттям - доброчесності, справедливості як «природній доброчесності», рівності, аби погодитися, що смак не дотичний до «моральності в їі почуттєвому стані».

Прискіплива увага до стану англійської гуманістики саме XVIII століття в сучасних умовах видається нам цілком слушною, оскільки їі сукупний досвід, помітно вплинувши на $1800-1850$ роки, яскраво віддзеркалився і в розвитку гуманітарного знання впродовж наступних п'яти десятиліть. Оскільки у наших розвідках «Теоретичний потенціал "Принципів мистецтва" Р.Дж. Коллінгвуда: досвід сучасних інтерпретацій» та «Мистецтвознавча концепція Р.Дж. Коллінгвуда як об'єкт теоретичного аналізу», що вийшли друком у 2020 році, представлені теоретико-практичні орієнтації P. Сауті, У. Тернера, Дж. Рьоскіна, Ф.-Г. Бредлі, А. Гранта, Б. Бозанкета, у цій статті ми зосередимося на постатях Т. Карлейля та Ф. Лейтона, доробок яких у першій половині XIX століття став 
підгрунтям для теоретичних шукань дослідників його другої половини.

Наразі звернімо увагу на творчу спадщину T. Карлейля, основні праці якого — «Sartor Resartus» (1838), філософський біографічний роман, «Герої, шанування героїв та героїчне в історії» (1841), «Минуле і сучасне» (1843) - були написані впритул до другої половини XIX століття, а отже безпосередньо сприймалися та оцінювалися вже читачами та науковцями цього часового відрізку.

Як відомо, Т. Карлейль перебував під помітним впливом як пізнього німецького романтизму, так і манери філософування, популярної на німецьких теренах. Своєрідний англо-німецький діалог, який закладався упродовж XVIII століття, знайшов своїх прибічників і у першій половині XIX. Т. Карлейль поділяв соціальний консерватизм німців, додаючи до цього власне неприйняття капіталізму. Професійно займаючись, окрім естетики та літературознавства, питаннями історії, він мав змогу об'єктивно інтерпретувати «за» i «проти» європейського історико-культурного розвитку впродовж 20-80-х років XIX століття.

Як естетик, Т. Карлейль високо цінував мистецтво, передусім, поезію, вважаючи, що і мистецтво загалом, і поезія зокрема мають виконувати виховну функцію, яка у теоретичному аспекті проголошувалася найважливішою. При цьому, він намагається по-новому тлумачити тезу Гете, який вважав, що Всесвіт - лише «живе втілення божества», а отже «божественною поезією» просякнутий космос. Поезія, яка в розмислах Карлейля, набуває метафоричного забарвлення, поєднуючись у його естетиці 3 проблемою «герой — героїчне», інтерпретується і в історичному, і в естетико-мистецтвознавчому аспектах. 3 цього приводу В. Панченко наголошує, що для Карлейля «історія світу є лише біографією великих людей», що ії теоретик зображує низкою «типів героя і виявів героїзму: спочатку герой виступає як божество, потім як пророк, поет, пастир i, нарешті, як вождь» (Панченко, 2010а: 103). Цю «біографію великої людини» і показує поезія, створюючи шедеври «героїчного епосу» у відповідні періоди історії.

Зосереджуючи увагу на сутності героя, теоретик актуалізує порівняльний аналіз, засади якого дають йому можливість представити переваги поезії порівняно з різними науками. Так, поезія дає цілісне бачення «матеріалу», з яким вона працює, і спрямовує людину на «героїчно-піднесене», яке, за певних умов, може пережити і пересічна людина, оскільки існує «поезія історії». Натомість нау- ка, порівняно з поезією, програє по всіх позиціях, залучаючи аналіз, розчленовує об'єкт, позбавляючи його зовнішніх обрисів і руйнуючи форму (Карлейль, 1994).

Говорячи про теоретико-практичне підгрунтя, на яке спиралася англійська гуманістика першої половини XIX століття, слід віддати належне надзвичайно яскравому і самобутньому живописцеві Фредеріку Лейтону (1830-1896), який стояв біля витоків руху «прерафаелітів» і належав до представників «елітарних» англійських живописців. У сімнадцять років він у Франкфурті випадково зустрів А. Шопенгауера і написав його портрет, який до сьогодні вважається найбільш об'єктивним зображенням філософа.

Отримавши освіту в лондонському «University College School», Лейтон багато подорожує, вивчаючи традиції східного мистецтва у Сирії та Єгипті. Задля удосконалення професійних навичок він їде до Італії, а між 1855-1859 роками живе в Парижі, де активно спілкується з Е. Делакруа та К. Коро, високо оцінюючи їх творчу манеру. Повернувшись до Лондона, Лейтон багато працює, не обмежуючи себе якимось одним жанром образотворчого мистецтва. Якщо у жанрі портрета, якому митець приділяв значну увагу, він продовжує чинні традиції, то в інших своїх роботах сміливо експериментує як з композицією полотен, так і з їх кольоровим вирішенням (Лейтон, https:// wm-painting.ru/L/p2 articleid/912).

На нашу думку, однією з найкращих робіт не лише Лейтона, а й усього англійського живопису кінця XIX століття, слід визнати «Палаючий червень» (1895), яка зображує жінку у вільній червоній сукні із сміливим ракурсом тіла, що ніяк не стикується 3 манірно-регламентованими постатями на більшості полотен тогочасних відомих живописців. Принагідно зазначимо, що Лейтон блискуче передавав на полотні саме червоний колір, що підтверджує і його «Автопортрет» (1880).

Висновки. Підсумовуючи матеріал, викладений у статті, наголосимо на такому:

1. Зазначено, що в історії англійської філософіï, яка розвивалася послідовно, від століття до століття збагачуючи напрацьований теоретичний досвід, кінець XVII і XVIII століття виявилися доволі продуктивними і такими, що вплинули на наступний історико-культурний період. Окреслено певні наукові розвідки, які в умовах XXI століття корегують джерелознавчу базу попередніх десятиліть;

2. Наголошено, що серед низки теоретико-методологічних засад, на які в сучасних умовах спи- 
раються науки соціально-гуманітарного циклу, в процесі аналізу історико-філософської проблематики мають бути задіяні принципи культурологічного аналізу, зокрема, персоналізація та потенціал регіонального підходу;

3. Виокремлено тих персоналій англійської філософії - А.-Е. Шефтсбері, Ф. Бекон, Дж. Бейлі, Е. Бйорк, Д. Юм, Т. Карлейль, теоретичні напрацювання яких помітно вплинули на розвиток англійської гуманістики як першої, так і другої половини ХІХ століття.

\section{Бібліографія}

Банфи, А. (1989). Философия искусства: монография; пер с итал. Г. П. Смирнова. Москва: Искусство. 384 с.

Дэвид Юм. Режим доступу http://solecity.ru/philosophy/davidum

Дэвид Юм. David Hume. Режим доступу https://livelib.ru/ author/16159-devid-yum

Карлейль, Т. (1994). Теперь и прежде: сборн. переводов. Москва: Республика. 415 с.

Коллингвуд, Р.-Дж. (1980). Идея истории; Автобиография: сборн. материалов. Москва: Наука. 486 с.

Лейтон, Фредерик (Leighton, Frederic). Режим доступу https:// wm-painting.ru/L/p2_articleid/912

Оніщенко, О. І. (2010). Художня творчість: досвід естетичного аналізу. Левчук, Л.Т., Панченко, В. І., Оніщенко, О. І., Кучерюк, Д. Ю. Естетика: підручник. За заг. ред. Л. Т. Левчук. Вид. 3-тє переробл. і доп. Київ: Центр учбової літератури. 520 с. С. 267-313.

Панченко, В. І. (2010а). Основні естетичні категорії. Левчук, Л. Т., Панченко, В. І., Оніщенко, О. І., Кучерюк, Д. Ю. Естетика: підручник. Київ: Центр учбової літератури. C. 76-120.

Панченко, В. І. (2010b). Структура естетичної свідомості. Левчук, Л. Т., Панченко, В. І., Оніщенко, О. І., Кучерюк, Д. Ю. Естетика: підручник. Київ: Центр учбової літератури. С. $54-75$.

Петров, Ю. В. (2001). «Самый независимый ум всего XVIII столетия». Юм, Д. О человеческой природе: монография. СПб: Азбука.

Сэр Фредерик Лейтон. Режим доступу https://artchive.ru/ fredericleighton

Фишер, К. (2003). Фрэнсис Бэкон Веруламский: реальная философия и её эпоха. Москва: АСТ Ермак. $541 \mathrm{c}$.

Шадманов, К. Б. (2018). К истории становления системы основных понятий английской философии: философская плоскость. Вісник Маріупольського державного університету. Вип. 16. С. 25-32.

Юм, Д. (2001а). Автобиография. Юм, Д. О человеческой природе: монография. СПб: Азбука.

Юм, Д. (2001b). О человеческой природе: сборник. СПб: Азбука. $320 \mathrm{c.}$
Mossner, E.-C. (1950, april). Philosophy and biography: the case of David Hume. The Philosophical Review (Vol. 59, No. 2, pp. 184-201).

\section{References:}

Banfi, A. (1989). Filosofija iskusstva: Monohrafija [Philosophy of art]. Moskva: Iskusstvo [in Russian]

Carlyle, T. (1994). Teper'i prezhde: Sbornik perevodov [Past and Present]. Moskva: Respublika. [in Russian]. DOI: https://doi. org/10.1007/978-1-349-00484-3_23

Collingwood, R. G. (1980). Ideja istorii; Avtobiografija: Sbornik materialov [The Idea of History; Autobiography] [in Russian]. DOI: https://doi.org/10.2307/2181408

David Hume. Retrieved from http://solecity.ru/philosophy/david-um [in Russian]

David Hume. Retrieved from https://livelib.ru/author/16159-devid-yum [in Russian]

Fischer, K. (2003). Frjensis Bjekon Verulamskij: real'naja filosofija i ejo jepoha [Francis Bacon of Verulam: Realistic Philosophy and Its Age]. Moskva: AST Ermak. [in Russian]

Hume, D. (2001a). Avtobiografija [Autobiography]. Hume, D. O chelovecheskoj prirode: Monohrafija [About Human Nature]. Saint Petersburg: Azbuka. [in Russian]

Hume, D. (2001b). O chelovecheskoj prirode: Sbornik [About Human Nature]. Saint Petersburg: Azbuka. [in Russian]

Leighton, Frederic. Retrieved from https://wm-painting.ru/L/ p2_articleid/912 [in Russian]

Mossner, E.-C. (1950, april). Philosophy and biography: the case of David Hume. The Philosophical Review (Vol. 59, No. 2, pp. 184-201). [in English]. DOI: https://doi. org/10.2307/2181501

Onishchenko, O. I. (2010). Khudozhnia tvorchist: dosvid estetychnoho analizu [Artistic creativity: experience of aesthetic analysis]. Levchuk, L. T., Panchenko, V. I., Onishchenko, O. I. \& Kucheriuk, D. Yu. Aesthetics: Pidruchnyk. Kyiv: Tsentr uchbovoi literatury, pp. 267-313. [in Ukrainian]

Panchenko, V. I. (2010a). Osnovni estetychni katehorii [The main aesthetic categories]. Levchuk, L. T., Panchenko, V. I., Onishchenko, O. I. \& Kucheriuk, D. Yu. Aesthetics: Pidruchnyk. Kyiv: Tsentr uchbovoi literatury, pp. 76-120. [in Ukrainian]

Panchenko, V. I. (2010b). Struktura estetychnoi svidomosti [The structure of aesthetic consciousness]. Levchuk, L. T., Panchenko, V. I., Onishchenko, O. I. \& Kucheriuk, D. Yu. Aesthetics: Pidruchnyk. Kyiv: Tsentr uchbovoi literatury, pp. 54-75. [in Ukrainian]

Petrov, Ju. V. (2001). «Samyj nezavisimyj um vsego XVIII stoletija» [«The most independent mind of the 18th century»]. Hume, D. O chelovecheskoj prirode: Monohrafija [About Human Nature]. Saint Petersburg: Azbuka. [in Russian]

Shadmanov, K. B. (2018). K istorii stanovlenija sistemy osnovnyh ponjatij anglijskoj filosofii: filosofskaja ploskost' [To the history of formation of a system of basic concepts of English philosophy: philosophical plane]. Visnik Mariupol's 'kogo derzhavnogo universitetu, 16, pp. 25-32. Retrieved from http:// visnyk-culturology.mdu.in.ua/uk/vipusk_16.pdf [in Russian]

Sir Frederic Leighton. Retrieved from: https://artchive.ru/fredericleighton [in Russian] 


\section{Maryna Ternova}

\section{Historical and philosophical basis of English humanistics latter half of the nineteenth century}

Abstract. The article focuses on the historical and philosophical achievements that provided the theoretical basis for the humanistics of the latter half of the $19^{\text {th }}$ century. Since in English-speaking territories the humanities knowledge was formed on clearly expressed principles of succession, it is extremely important to take into account the experience that preceded the last half of the $19^{\text {th }}$ century. Its formation also presupposed openness both to new areas of research and to the outline of ways for the development of social, ethical and practical philosophy.

One of the fingerprints of this article is the use of the principles of culturological analysis, among which particular importance is attached to the personalization of the material being studied. We use personalization as a structural element of the biographical method, which allows us to confirm the human-creation nature of culture.

The article also emphasizes the importance of the gradual formation of a regional approach, which, starting from the $18^{\text {th }}$ century, was determined by the elements of dialogue between English-German and English-French humanistics.

Keywords: history of philosophy, aesthetics, art history, empiricism, scepticism, experience, «beautiful — sublime», «hero — heroism», «common sense».

\section{Терновая Марина Владимировна}

\section{Историко-философские основы английской гуманистики второй половины XIX столетия}

Аннотация. В статье сфокусировано внимание на тех историко-философских достижениях, которые сформировали теоретическое основание гуманистики второй половины XIX столетия. Поскольку в английских традициях гуманитарное знание чётко опиралось и использовало принцип преемственности, учитывать опыт, который предшествует второй половине XIX столетия, представляется крайне важным. Формирование такого опыта предусматривало также открытость для новых направлений исследований и предвидения путей развития социальной, моральной и практической философии.

Одним из специфических аспектов данной статьи является использование принципов культурологического анализа, среди которых особенное значение приобретает персонализация исследуемого материала. Персонализация - структурный элемент биографического метода, позволяющий подтвердить человекотворческий характер культуры, который последовательно разрабатывают украинские культурологи.

В статье также подчёркнуто значение постепенного формирования регионального подхода, который, начиная с XVIII столетия, определялся элементами диалога англо-немецкой и англо-французской гуманистики.

Ключевые слова: история философии, эстетика, искусствоведение, эмпиризм, скептицизм, опыт, «прекрасное - возвышенное», «герой — героизм», «общее чувство». 